\title{
LIPID PROFILE OF ADULT NIGERIANS ATTENDING MEDICAL OUTPATIENT CLINIC OF BAPTIST MEDICAL CENTRE OGBOMOSO
}

\author{
*I O Amole, *DA OlaOlorun
}

*Department of Family Medicine, Baptist Medical Centre (now Bowen University Teaching Hospital) Ogbomoso, Oyo State, Nigeria.

\section{Correspondence:}

I.O. Amole

Department of Family Medicine,

Bowen University Teaching Hospital,

P.O. Box 15,

Ogbomoso, Oyo State, Nigeria.

E-mail: amoleio@yahoo.com

Tel: +2348057078851

\begin{abstract}
Background: Economic development and urbanization in many developing countries has led to a nutritional transition characterized by a shift to a higher caloric content of diet and/or to the reduction of physical activity, and whose consequences are changes in the body composition of the individuals and elevated blood lipid levels. This study's aim was to determine the lipid profile and to determine if there is any association between lipid profile and abdominal obesity among adults attending the outpatient clinic at the Baptist Medical Centre, Ogbomoso, a semi urban environment.
\end{abstract}

Methods: A cross-sectional descriptive study of 400 adults aged 18 years and above was carried out. Participants were administered a standardized questionnaire and had measurements of waist circumference and serum lipids taken.

Results: Four hundred subjects were randomly selected (221 females and 179 males) with a mean age of $48.65 \pm$ 16.56 years. The mean total cholesterol, LDL- cholesterol, Triglycerides and HDL-cholesterol were $3.78 \pm 1.07 \mathrm{mmol} / \mathrm{L}, 1.18 \pm 1.02$ $\mathrm{mmol} / \mathrm{L}, 0.97 \pm 0.58 \mathrm{mmol} / \mathrm{L}$ and 2.15 $\pm 0.86 \mathrm{mmol} / \mathrm{L}$ respectively. The prevalence of abdominal obesity among the study population was $33.75 \%$. The subjects who had abdominal obesity had the highest mean values for total cholesterol, triglycerides, LDL-cholesterol and HDL-cholesterol. The mean values of total cholesterol, HDL-cholesterol, triglycerides and LDL-cholesterol obtained among the physically inactive subjects were higher than those of the subjects who were physically active. Conclusion: Higher mean values for total cholesterol, triglycerides and LDLcholesterol were found among the subjects who had abdominal obesity and those who were physically inactive in Ogbomoso.

Keywords: Lipid profile, abdominal obesity, physical activity, Nigeria.

\section{INTRODUCTION}

For several decades profound demographic and economic changes that many developing countries have witnessed has created completely new conditions in terms of lifestyle. With urbanization and economic development has emerged a nutritional transition characterized by a shift to a 
higher caloric content of diet and/or to the reduction of physical activity, and whose consequences are changes in the body composition of the individuals and elevated blood lipid levels.

Serum lipid is measured as total cholesterol and its fractions; high density lipoprotein (HDL) cholesterol, low density lipoprotein (LDL) cholesterol, very low density lipoprotein (VLDL) cholesterol and triglycerides. Abnormal blood lipid levels, which is high total cholesterol, high levels of triglycerides, high levels of low-density lipoprotein or low levels of high-density lipoprotein cholesterol, all increase the risk of atherosclerosis and coronary artery disease. ${ }^{2}$

The association between coronary artery disease and cholesterol is continuous throughout the range of cholesterol levels in the population and becomes stronger at higher levels. ${ }^{3}$ Studies have shown that the socioeconomic status, obesity and physical activity influence the lipid profile. $^{2}$

\section{Study Area}

Ogbomoso is located about $100 \mathrm{~km}$ north of Ibadan, the Oyo State capital in Southwest Nigeria. The indigenous people are from the Yoruba ethnic group. The majority of them engage in farming or trading. There are two degree- awarding institutions in Ogbomoso ï Ladoke Akintola University of Technology and The Nigerian Baptist Theological Seminary which attract people from other ethnic groups into the town. A governmentowned general hospital, a Baptist mission hospital, a few Primary Health Care centres and an increasing number of private hospitals meet the health needs of the people.

\section{Patients and Methods}

Approval was obtained from the Ethics Committee of the Baptist Medical Centre, Ogbomoso before the commencement of the study. The study was conducted at the medical out-patientsô clinic between January, 2008 and July, 2008. Informed consent was also obtained from the subjects before their enrolment to participate in the study.

A cross-sectional descriptive survey was used. Subjects aged 18 years and older who gave consent for the study were recruited. Subjects on anti-lipid drugs, pregnant women, women in the puerperium (day of delivery to 6weeks post delivery), patients with ascites and intrabdominal masses determined through history and physical examination were excluded from the study. A systematic sampling method was used to select the subjects. The list of patients who were registered each day to see the doctor at the medical out-patientsô clinic was taken as a sample frame, and from a review of records, an average of 100 patients were estimated to attend the medical outpatient clinic per day during the period of the study. A sampling fraction of 10 was chosen and a simple random sampling was done to pick the first subject from the first ten patients as the starting number of the systematic sampling technique, subsequent selections were every $10^{\text {th }}$ registered patient on the register. An identification sticker was placed on all selected subjectsô record cards from the records office, where the sampling was done and sent to a designated consulting office for the study. An identification sticker was left on all selected subjectsôcards until the study was over to avoid a repeat selection.

A pre-tested questionnaire was administered by the researcher to obtain the following information: age, sex, marital status, ethnic group, religion, nationality, occupation, educational status and physical activity.

The waist circumference was measured in centimetres using a flexible non-stretchable tape measure. The waist circumference was taken at the midpoint between the lower rib border and iliac crest at the end of expiration with the subjects in standing position. ${ }^{4}$ Abdominal overweight was 
defined as WC between $94 \mathrm{~cm}$ and $101 \mathrm{~cm}$ for men and between $80 \mathrm{~cm}$ and $87 \mathrm{~cm}$ for women, while abdominal obesity was defined as WC Ó $102 \mathrm{~cm}$ and $\mathrm{O} 88 \mathrm{~cm}$ for men and women respectively. ${ }^{5}$

The subjects were requested to fast overnight. Blood sample was obtained in the morning after a 1214 hour fast. A tourniquet was applied proximal to the area of venepuncture either above the wrist or elbow joint, the area cleansed with methyl alcohol swab and $3 \mathrm{mls}$ of blood drawn from a distended vein with a size 21G hypodermic needle attached to a $5 \mathrm{ml}$ syringe. The tourniquet was released immediately after blood samples were taken and pressure applied to stop bleeding, using dry cotton wool. The blood sample was put in a lithium heparin bottle. The blood was centrifuged (at $3000 \mathrm{rpm}$, for $10 \mathrm{~min}$ ) about 30minutes after, and stored at $4^{0} \mathrm{C}$ in plain plastic bottles overnight if analysis was not done the same day. The estimation of total cholesterol, HDL-cholesterol and triglycerides were done using the colorimetric method. All the analyses were done by a qualified Laboratory Scientist. The LDLcholesterol was calculated using the formula. ${ }^{6}$

$\mathrm{LDL}=$ Total cholesterol $-\frac{(\mathrm{HDL}+\text { Triglycerides })}{22}$

Lipid profile was analysed using the European recommended blood lipid level and the values were as follows: total cholesterol $<5.0 \mathrm{mmol} / \mathrm{L}$, LDLcholesterol $<3.0 \mathrm{mmol} / \mathrm{L}$, HDL-cholesterol $>1.0 \mathrm{mmol} / \mathrm{L}$ men, $>1.2 \mathrm{mmol} / \mathrm{L}$ women and triglycerides $<1.7 \mathrm{mmol} / \mathrm{L}^{2}{ }^{2}$

The subjects who engaged in leisure time physical activity (walking, fitness training and sports) for greater than or equal to three times per week of thirty minutes per occasion were classified as physically active.

The subjects were placed into one of the five social classes based on their occupation using the Registrar

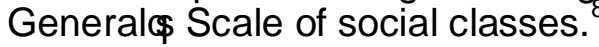

Class 1: Professional e.g. Lawyer, Doctor, Accountant.

Class 2: Intermediate e.g. Teacher, Nurse, Manager.

Class 3N: Skilled non-manual e.g. Typist, Shop assistant, telephone operators.

Class 3M: Skilled manual e.g. Miner, Bus-driver, Cook, artisans.

Class 4: Partly skilled (manual) e.g. Farm worker, Bus conductor.

Class 5: Unskilled e.g. Cleaner, Labourer.

Data were analyzed by computer using the Statistical Package for Social Sciences (SPSS version 13).

\section{Results}

A total of 400 subjects aged 18 years and older were recruited for the study. The mean age of the subjects was $48.65 \pm 16.57$ years and there were more females $(55.25 \%)$ than males (44.75\%). The mean total cholesterol was $3.78 \pm 1.07 \mathrm{mmol} / \mathrm{L}$ with a male mean of $3.57 \pm 1.00$ $\mathrm{mmol} / \mathrm{L}$ and a female mean of $3.94 \pm$ $1.10 \mathrm{mmol} / \mathrm{L}$. The mean LDLcholesterol was $1.18 \pm 1.02 \mathrm{mmol} / \mathrm{L}$ with a male mean of $1.11 \pm 0.98$ $\mathrm{mmol} / \mathrm{L}$ while the mean in the female was $1.13 \pm 1.05 \mathrm{mmol} / \mathrm{L}$. The mean serum triglyceride was $0.97 \pm 0.58$ $\mathrm{mmol} / \mathrm{L}$, the male mean was $0.94 \pm$ $0.54 \mathrm{mmol} / \mathrm{L}$ and the female mean was $0.99 \pm 0.62 \mathrm{mmol} / \mathrm{L}$. The mean HDLcholesterol was $2.15 \pm 0.86 \mathrm{mmol} / \mathrm{L}$ with a male mean of $2.04 \pm 0.87$ $\mathrm{mmol} / \mathrm{L}$ and a female mean of $2.24 \pm$ $0.84 \mathrm{mmol} / \mathrm{L}$ (Table 1).

Analysis of mean total cholesterol, LDL-cholesterol and triglycerides among the different age groups show a steady increase with increasing age. The physically inactive subjects had the higher mean values of total cholesterol $(t=0.682 ; p=0.02)$, HDLcholesterol $(\mathrm{t}=-2.418 ; \mathrm{p}=0.016)$, triglycerides $(t=-1.690 ; p=0.092)$ and LDL-cholesterol $(t=-0.719 ; p=0.472)$ than the subjects who were physically active. The subjects from the social class one had the highest mean values for the total cholesterol, triglycerides and LDL-cholesterol (Table 2). 
Among the study population, $13.75 \%$ had high level of total cholesterol, $7.25 \%$ had low level of HDL-cholesterol, $10.50 \%$ had high level of triglycerides while $6.25 \%$ had high level of LDL-cholesterol (Table 3).

The prevalence of abdominal obesity and overweight among the study population were $33.75 \%$ and $17.50 \%$ respectively. Almost one-half $(48.75 \%)$ of the study population had normal waist circumference. The subjects who had abdominal obesity had the highest mean values for total cholesterol, triglycerides, LDLcholesterol and HDL-cholesterol (Table 2).

\section{DISCUSSION}

This study revealed a mean total cholesterol level of $3.78 \pm 1.07$ $\mathrm{mmol} / \mathrm{L}$. This finding is similar to what was found in Benin $(3.64 \mathrm{mmol} / \mathrm{L})$ and Jos $^{10}(3.54 \mathrm{mmol} / \mathrm{L})$ but at variance to what was found in Port-Harcourt ${ }^{3}$ $(4.76 \mathrm{mmol} / \mathrm{L})$ and Lagos ${ }^{11}$ (4.28mmol/L). The higher value obtained in PortHarcourt and Lagos may be as a result of differences in the social classes of the subjects in which almost one-half of the study population in Ogbomoso were from social class $3 \mathrm{~N}(42.8 \%)$ while the majority of subjects from Port-Harcourt were from social classes 1 and 2 . Another reason may be the difference in the lifestyles. The lifestyles of the residents of PortHarcourt and Lagos being similar to the western lifestyle and that of Ogbomoso residents still largely rural.

Several studies ${ }^{3,9,10}$ have reported relatively lower levels of lipid profile in Africans than their Caucasian counterparts. This is also supported by this study and apart from the difference in the lifestyle, the reference value used in this study is the one used in Europe, so that may be another reason for the relatively lower levels of lipid in Ogbomoso. The prevalence of obesity based on waist circumference was $33.75 \%$. The prevalence of obesity based on waist circumference found in this study is comparable with $31.7 \%$ for waist circumference found in Okrika, Rivers State, Nigeria by Siminialayi et al. ${ }^{12}$ The situation is similar in Cotonou, Benin Republic where Sodjinou et al ${ }^{13}$ found an overall prevalence of abdominal obesity of $32.0 \%$.

Several studies ${ }^{12}$ have established strong relationship between abdominal obesity and abnormal lipid levels. This was also confirmed in this study where the subjects who had abdominal obesity had highest mean values for total cholesterol, triglycerides, HDLcholesterol and LDL-cholesterol.

It was discovered from this study that physical inactivity contributes to the development of abnormal lipid levels. The mean values of total cholesterol, HDL-cholesterol, triglycerides and LDL-cholesterol obtained among the physically inactive subjects were higher than those of the subjects who were physically active.

\section{CONCLUSION}

Higher mean values for total cholesterol, triglycerides and LDLcholesterol were found among the subjects who had abdominal obesity and those who were physically inactive in Ogbomoso.

There is need for promotion of lifestyle modification in Ogbomoso to reduce the prevalence of obesity and thereby prevention development of abnormal lipid levels.

Since abdominal obesity is strongly associated with hyperlipidemia, waist circumference may be useful as a simple and inexpensive screening tool to select individuals eligible for more sophisticated and costly serum lipid determinations, especially in developing countries.

\section{REFERENCES}

1. Pasquet $P$, Temgoua LS, Melaman-Sego $F$, Froment $A$, Rikong-Adie $\mathrm{H}$. Prevalence of overweight and obesity for urban adults in Cameroon. Ann Hum Biol. 2003;30(5):551-562. 
2. World Heart Federation. Cardiovascular disease risk factorscholesterol. (Online). 2005. (cited 2008 Oct 22); Available from: URL: http://www.world-heart-federation. org/cardiovascular health/cardiovascular-disease-riskfactors/ cholesterol.

3. Kappa MR, Agomouh DI, Alasia DD. Lipid profile of healthy adult Nigerians in Port-Harcourt, Nigeria. Niger J Med 2006;15(2):137-40.

4. World Heart Federation. Healthy weight, healthy shape. (Online). 2005. (cited 2008 Oct 17); Available from: URL hppt://www. worldheartday.com/articules/Health yweightshape-booklet

5. The European Food Information Council. Obesity and overweight. (Online). 2006. (cited 2008 Oct 22); Available from: URL: http://www. eufic.org/article/en/expid/basicsobesity-overweight/

6. Lawrence MT, Stephen JM, Maxin AP. Current medical diagnosis and treatment. $43^{\text {rd }}$ ed. New York: Lange Medical Books/ McGrawHill; 2004. p. 348.

7. Physical Activity and Health: A report of the Surgeon General. Washington DC: US department of health and human services. (Online) 2008 Jan. (cited 2008 Oct 17); Available from: URL http://www.surgeongeneral.gov/libr ary/disabilities/calltoaction/whatitm eanstoyou.htm|\#choose
8. Social Research Update. (Online). 1995 July. (cited 2008 Oct 17); Available from: URL http://sru.soc. surrey.ac.uk/SRU9.html

9. Ukoli FAM, Bunker $\mathrm{CH}$, Fabio $\mathrm{A}$, et al. Sex differences in serum lipids pattern and their correlates in a Nigerian Urban Elderly Population. Nig Med J 1997; 32(3) 85-89.

10.Dac SC, Isichei UP. Beta lipoprotein cholesterol, beta lipoprotein and triglycerides in a healthy Nigerian population. Nigerian postgraduate medical journal 1997;4(3):88-92.

11. Onitiri A, Sander M, Boyo AE. Serum lipids and lipoproteins in healthy. Africans. Clin Chem Acta 1977; 811:57-61.

12. Siminialayi IM, Emem-Chioma PC, Dapper DV. The prevalence of obesity as indicated by BMI and waist circumference among Nigerian adults attending Family Medicine clinics as outpatients in Rivers State. Niger J Med 2008; 17(3):340-5.

13. Roger S, Victoire A, Benjamin F, Hélène D. Obesity and cardiometabolic risk factors in urban adults of Benin: Relationship with socio-economic status, urbanisation, and lifestyle patterns. BMC Public Health 2008;8:84. 
Table 1: $\quad$ Mean values of lipid profile

\begin{tabular}{|l|c|c|c|}
\hline \multirow{2}{*}{\multicolumn{1}{c}{ Lipid Profile }} & \multicolumn{3}{c|}{ Mean and standard deviation } \\
\cline { 2 - 4 } & Male & Female & Total \\
\hline Totalcholesterol (mmol/L) & $3.57 \pm 1.00$ & $3.94 \pm 1.10$ & $3.78 \pm 1.07$ \\
\hline Triglycerides (mmol/L) & $0.94 \pm 0.54$ & $0.99 \pm 0.62$ & $0.97 \pm 0.58$ \\
\hline HDL-Cholesterol (mmol/L) & $2.04 \pm 0.87$ & $2.24 \pm 0.84$ & $2.15 \pm 0.86$ \\
\hline LDL-Cholesterol (mmol/L) & $1.11 \pm 0.98$ & $1.13 \pm 1.05$ & $1.18 \pm 1.02$ \\
\hline
\end{tabular}

Table 2: $\quad$ Age range, social class, physical activity, abdominal obesity and mean values of lipid profile

\begin{tabular}{|c|c|c|c|c|}
\hline & $\begin{array}{c}\text { TCL } \\
\text { (mmol/L) }\end{array}$ & $\begin{array}{c}\text { TRG } \\
\text { ( } \mathrm{mmOl} / \mathrm{L})\end{array}$ & $\begin{array}{c}\text { HDL } \\
\text { (mmol/L) }\end{array}$ & $\begin{array}{c}\text { LDL } \\
\text { (mmol/L) }\end{array}$ \\
\hline \multicolumn{5}{|c|}{ Age range (years) } \\
\hline $18 \ddot{i} 19$ & 2.97 & 1.13 & 2.04 & 0.38 \\
\hline 20 ï 29 & 3.32 & 0.82 & 2.09 & 0.85 \\
\hline 30 ï 39 & 3.77 & 0.86 & 2.17 & 1.20 \\
\hline 40 ï 49 & 3.83 & 0.93 & 2.12 & 1.28 \\
\hline 50 ï 59 & 3.99 & 1.05 & 2.29 & 1.22 \\
\hline 60 ï 69 & 3.81 & 0.55 & 2.07 & 1.26 \\
\hline$\geq 70$ & 3.79 & 1.04 & 2.04 & 1.28 \\
\hline \multicolumn{5}{|l|}{ Social Class } \\
\hline Class 1 & 4.13 & 0.52 & 2.90 & 0.99 \\
\hline Class 2 & 3.81 & 0.93 & 2.23 & 1.15 \\
\hline Class 3N & 3.97 & 0.99 & 2.22 & 1.29 \\
\hline Class $3 \mathrm{M}$ & 3.32 & 0.93 & 1.85 & 1.04 \\
\hline Class 4 & 3.20 & 0.98 & 1.78 & 0.97 \\
\hline Class 5 & 3.71 & 0.99 & 2.11 & 1.14 \\
\hline \multicolumn{5}{|c|}{ Physical Activity } \\
\hline Active & 3.57 & 0.91 & 2.02 & 1.14 \\
\hline Inactive & 3.90 & 1.01 & 2.23 & 1.21 \\
\hline \multicolumn{5}{|c|}{ Abdominal Obesity } \\
\hline Obese & 4.11 & 1.06 & 2.31 & 1.32 \\
\hline Overweight & 3.88 & 1.01 & 2.14 & 1.27 \\
\hline Normal & 3.48 & 0.89 & 2.02 & 1.04 \\
\hline
\end{tabular}

$\mathrm{TCL}=$ Total cholesterol

$T R G=$ Triglycerides

$\mathrm{HDL}=$ High density lipoprotein cholesterol

$\mathrm{LDL}=\mathrm{Low}$ density lipoprotein cholesterol 
Table 3: $\quad$ Lipid profile of the subjects

\begin{tabular}{|c|c|c|}
\hline Variables & Frequency & Percentage \\
\hline $\begin{array}{l}\text { Total Cholesterol } \\
\text { High } \\
\text { Normal }\end{array}$ & $\begin{array}{r}55 \\
345\end{array}$ & $\begin{array}{l}13.75 \\
86.25\end{array}$ \\
\hline $\begin{array}{l}\text { Triglyceride } \\
\text { High } \\
\text { Normal }\end{array}$ & $\begin{array}{r}4 \\
358\end{array}$ & $\begin{array}{l}10.50 \\
89.50\end{array}$ \\
\hline $\begin{array}{l}\text { LDL-CHOLESTEROL } \\
\text { High } \\
\text { Normal }\end{array}$ & $\begin{array}{r}25 \\
375\end{array}$ & $\begin{array}{r}6.25 \\
93.75\end{array}$ \\
\hline $\begin{array}{l}\text { HDL-CHOLESTEROL } \\
\text { Low } \\
\text { Normal }\end{array}$ & $\begin{array}{r}29 \\
371\end{array}$ & $\begin{array}{r}7.25 \\
92.75\end{array}$ \\
\hline $\begin{array}{l}\text { TCL:HDL } \\
\text { High } \\
\text { Normal }\end{array}$ & $\begin{array}{r}14 \\
386\end{array}$ & $\begin{array}{r}3.50 \\
96.50\end{array}$ \\
\hline
\end{tabular}

